\title{
PEMBUKTIAN TINDAK PIDANA PEMBUNUHAN BERDASARKAN KETERANGAN SAKSI MAHKOTA Analisa putusan : 334/pid.B/2014/PN/Dpk
}

\section{Hamdan}

Fakultas Ekonomi Universitas Pamulang

Email : hamdannurohimi234@gmail.com

\section{Received: Mei 2019/Revised: Mei 2019/Accepted: Ags 2019}

\begin{abstract}
Penerapan saksi mahkota dalam kasus pembunuhan dalam putusan No: 334/ Pid.B./2014. dengan cara pemisahan berkas perkara dimana terdakwa farilham jayadi menjadi saksi untuk berkas terdakwa sarifudin dan itupun sebaliknya, sebagaimana Pasal 142 Kitab Undang- Undang Acara Pidana (KUHAP), tujuan pemecahan berkas itu sendiri agar seorang terdakwa dengan terdakwa yang lain, masing-masing dapat dijadikan sebagai saksi secara timbal balik., sebagaimana pasal 168 huruf b KUHAP secara implisit mengatur tentang saksi mahkota. Selain itu pengaturan mengenai penerapan saksi mahkota juga bisa kita temukan dalam Putusan Mahkamah Agung No. $1986 \mathrm{~K} / \mathrm{Pid} / 1989$ tanggal 21 Maret 1990, yang pada pokoknya menjelaskan "Penuntut Umum/Jaksa diperbolehkan mengajukan teman terdakwa sebagai saksi, yang disebut "saksi mahkota (kroongetuige)", asalkan perkara terdakwa dipisahkan dari perkara saksi tersebut (terdakwa dan saksi tidak termasuk dalam satu berkas perkara, selain itu pemakaian saksi mahkota selain dibolehkan haruslah dengan alat bukti tambahan.
\end{abstract}

Kata kunci : Pembuktian, Pembunuhan, Saksi Mahkota

\begin{abstract}
Application of crown witnesses in murder cases in ruling No: 334 / Pid.B./2014. by separating case files where defendant farilham jayadi is a witness for the defendant sarifudin's files and vice versa, as Article 142 of the Criminal Procedure Code (KUHAP), the purpose of solving the file itself so that one defendant can be made as a witness in return., as article 168 letter $b$ of KUHAP implicitly governs the witness of the crown. In addition, we can find arrangements regarding the application of crown witnesses in the Decision of the Supreme Court No. 1986 K / Pid / 1989 dated March 21, 1990, which basically explained "Prosecutors / Prosecutors are allowed to submit a defendant's friend as a witness, called" witness
\end{abstract}


crown (kroongetuige)", provided the defendant's case is separated from the witness case (the defendant and witness are not included in one case file, besides the use of crown witnesses in addition to being allowed must be with additional evidence.

Keywords: Proof, Murder, Crown Witness.

\section{PENDAHULUAN}

Suatu tindak kejahatan menjadi topik yang menarik untuk menjadi sebuah perbincangan oleh kebanyakan orang terutama di negara Indonesia sebagai negara hukum yang termuat dalam pasal i ayat (3) undang-undang dasar 1945. yang mengandung arti bahwa didalam negara kesatuan republik Indonesia, hukum merupakan instrument atau sebagai sarana dalam melakukan aktivitas pada segala kehidupan berbangsa dan bernegara. Oleh karena itu prinsip- prinsip negara hukum haruslah berkembang sesuai dengan perkembangan masyarakat dan negara, yang terdapat dua belas prinsip pokok utama yang menyangga sebagai negara hukum ${ }^{\mathrm{I}}$.

Dalam rangka memberikan perlindungan hukum terhadap masyarakat, aparat penegak hukum memiliki peran menanggulangi gangguan yang berupa kejahatan baik dalam bentuk preventif maupun respresif. Penegakan hukum preventif adalah proses pelaksanaan hukum pidana dalam upaya mencegah terjadinya kejahatan, sedangkan secara represif adalah merupakan tindakan penegak hukum apabila terjadi kejahatan sebagai upaya pelaksanaan hukum pidana meliputi penyidikan, penuntutan dan penjatuhan hukuman.

Tujuan hukum adalah untuk melindungi kepentingan itu, jadi hukum melindungi kepentingan individu di masyarakat, dan atau melindungi kepentingan masyarakat secara keseluruhan.Atau dalam garis besarnya hukum mengabdi pada tujuan negara yang dalam pokoknya adalah mendatangkan kemakmuran dan kebahagian pada rakyatnya serta mengatur pergaulan hidup manusia secara damai. ${ }^{2}$

Sedangkan fungsi pemidanaan menjaga keseimbangan individu dengan kepentingan masyarakat dalam mencapai kesejahteraan bersama, yang mana semua aturan perundang - undangan mengenai hukum pidana subtantif hukum pidana formil dan hukum pelaksanaan pidana dapat dilihat sebagai satu kesatuan sebagai sistem pemidanaan yang mana beberapa ahli berpendapat untuk menakut-nakuti orang jangan sampai melakukan kejahatan, baik secara menakut-nakuti orang banyak (generale preventive) maupun dengan cara menakut-nakuti orang tertentu

${ }^{1}$ Jimly Asshiddihie.Menuju Negara Hukum Yang Demokratis, Jakarta:PT Bhuana Ilmu Populer,2009 ,hal.397

${ }^{2}$ Soedjono,AsasPenerapan Hukum Pidana,Jakarta:Fasco,1991,hal.113 
yang sudah menjalankan kejahatan agar dikemudian hari tidak melakukan kejahatan lagi (special preventive)3, tetapi seiring peradapan manusia yang makin kompleks, meskipun ketentuan - ketentuan mengenai perbuatan yang melawan hukum yang disertai sanksi pidana telah dituangkan dalam aturan hukum pidana, baik kejahatan ataupun pelanggaran tetap saja terjadi. Kejahatan merupakan suatu fenomena yang terus mengalami peningkatan baik secara kualitas maupun kuantitas.

Kejahatan terhadap nyawa dan tubuh berupa pembunuhan dan penganiayaan masih sering terjadi bukan hanya disaksikan melalui media tetapi juga sudah merambat di berbagai daerah termasuk di kota depok .kejahatan tersebut dilatar belakangi kecemburuan social .dendam dan factor psikologi seseorang, tetapi yang menjadi masalah adalah faktor pendidikan dimana kurangnya pendidikan yang dimiliki pelaku kejahatan juga sebagai salah satu pendukung pelaku dalam melakukan kejahatan. Dimana kurangnya pendididikan yang dimiliki pelaku menjadi tidak berpikir terlebih dahulu akan akibat dari tindakanya kemudian. Serta control sosial masyarakat baik terhadap pelaku maupun korban pembunuhan sehingga memberi peluang terjadinya pembunuhan atau perampasan nyawa orang lain.

Adapun hal yang perlu kita cermati adalah sistem peradilan terkadang masih belum menjamin sebuah proses peradilan yang jujur dan adil, dimana terdapat hukuman yang kurang adil atau kesalahan dalam penanganan perkara dengan hal tersebut maka penulis akan membahas pertimbangan hakim dalam menjatuhkan putusan terhadap tindak pidana pembunuhan yang dilakukan Secara Bersama-Sama dengan penerapan hukumnya sebagaimana saksi mahkota yang di dengar atas keterangannya sebagai alat bukti.

Setelah kita cermati KUHAP mengutamakan perlindungan hak asasi manusia,dan secara tersirat sebenarnya telah memuat mengenai asas non self incrimination yang tertera secara parsial melalui Pasal 66 KUHAP bahwa tidak ada beban kewajiban pembuktian bagi terdakwa (beban pembuktian menjadi kewajiban penuntut umum), Pasal i75 KUHAP yang menyiratkan adanya hak ingkar bagi terdakwa, Pasal I89 ayat (3) KUHAP bahwa keterangan terdakwa hanya dapat dipergunakan bagi dirinya sendiri, dan tidak adanya pengakuan terdakwa sebagai alat bukti yang sah sebagaimana diatur dalam Pasal I84 ayat (I) KUHAP, serta Pasal I68 KUHAP tentang pengecualian yang bersifat relatif untuk menjadi saksi. 
Atas dasar inilah.mendorong keingintahuan penulis untuk mengkaji lebih lanjut tentang penerapan hukum seorang saksi mahkota dalam tindak pidana pembunuhan yang dilakukan secara bersam-sama yang pernah terjadi di dekat pos pemuda pancasila dekat bensin biru Kel.Kalimulya Kec cilodong Kota Depok. analisa putusan nomor :334/pid.B/2014/PN/Dpk .

\section{PERMASALAHAN}

Berdasarkan latar belakang yang telah diuraiakan penulis tersebut terdapat pokok permasalahan dalam tulisan ini adalah pertama, apakah penerapan saksi mahkota sudah sesuai dengan aturan hukum yang berlaku dengan menjaga marwah hak asasi manusia ? serta peran saksi mahkota dalam menyingkap tabir perbuatan pembunuhan tersebut?

\section{METODOLOGI PENELITIAN}

Penulisan ini menggunkan metode yuridis normatif, yaitu penelitian terhadap norma-norma hukum pidana yang terdapat dalam peraturan perundang - undangan pidana Indonesia, dengan menggunakan metode deskritif analisis, data yang digunakan Primer adalah Putusan analisa putusan nomor :334/pid.B/2014/PN/Dpk data sekunder publikasi hukum seperti buku, hasil karya ilmiah, artikel dan internet.

\section{PEMBAHASAN}

\section{Tindak Pidana Pembunuhan Dengan Jenisnya}

Tindak pidana merupakan istilah dalam hukum pidana yang memiliki pengertian yang luas sehingga menimbulkan berbagai istilah dikalangan sarjana hukum. Namun arti tindak pidana tersebut pada dasarnya adalah sama sedangkan perbedaan istilah itu tergantung dari sudut mana para pakar memandang.

Tindak pidana (delik) berasal yang dikenal dalam istilah hukum pidana belanda yaitu strafbaarfeit yang juga dipakai oleh Kitab Undang Undang Hukum Pidana yang biasanya disebut KUHP tetapi tidak ada penjelasan resmi yang dimaksud dengan strafbaarfeit. Itu sendiri Dalam kamus besar Bahasa Indonesia delik itu sendiridi berikan batasan arti sebagai berikut " perbuatan yang dapat dikenakan hukuman karena merupakan pelanggaran terhadap Undang-Undang tindak pidana” 4

4

Kebudayaan,KamusBesarBahasaIndonesia,BalaiPustaka, 2001
DepartemenPendidikandan 
Sedangkan yang dimaksud tindak pidana pembunuhan adalah kesengjaan menghilangkan nyawa orang lain dalam KUHP disebut pembunuhan5. Untuk menghilangkan nyawa orang lain itu pelaku harus melakukan sesuatu rangkaian tindakan yang berakibat dengan meninggalnya oranglain dengan catatan bahwa Opzet dari pelakunya itu harus ditunjukan pada akibat berupa meninggalnya oranglain tersebut.dari uraian tersebut kiranya kita memahami secara jelas bahwa tindak pidana pembunuhan itu merupakan suatu delik materil, kiranya jelas bahwa yang tidak dikehendaki oleh Undang-Undang itu sebenarnya adalah kesengajaan menimbulkan akibat meninggalnya orang lain. Dari penjelasan ini bahwa tindak pidana pembunuhan ini merupakan suatu delik materiil yakni delik yang baru dapat dianggap sebagai telah selesai dilakukan oleh pelakunya dengan timbulnya akibat yang dilarang atau yang tidak dikehendaki oleh undang-undang.

Secara umum para pakar hukum pidana telah menerima adanya 3 bentuk kesengajaan ( opzet) yakni $:^{6}$

I. Kesengajaan sebagai maksud (opzet als oogmerk)

2. Kesengajaan dengan keinsafan pasti ( opzet als zekerheids bewustjin)

3. Kesengajaan dengan keinsafan kemungkinan (dolus eventualis)

\section{Tindak Pidana Pembunuhan Dalam Bentuk Pokok}

Di atas telah dijelaskan oleh pembentuk undang-undang bahwa pembunuhan dalam bentuk pokok itu diatur dalam pasal 338 KUHP yang berbunyi:“ barang siapa dengan sengaja menghilangkan nyawa orang lain, karena bersalah telah melakukan pembunuhan dipidana dengan pidana penjara selama-lamanya lima belas tahun"

Dari rumusan tindak pidana mengenai rumusan tindak pidana pembunuhan yang diatur dalam pasal $338 \mathrm{KUHP}$ di atas orang dapat mengetahui bahwa tindak pidana pembunuhan yang oleh pembentuk undang-undang telah disebut dengan kata doodslag itu mempunyai unsurunsur sebagai berikut: ${ }^{7}$

I. Unsur subjektif :opzetelijk atau dengan sengaja

2. Unsur objektif:

a) Beroven atau menghilangkan

b) Het leven atau nyawa

${ }^{5}$ Lamintang, delik- delik khusus kejahatan terhadap nyawa, tubuh \& kesehatan" Jakarta: sinar Grafika,2010,Hal 1

${ }^{6}$ Op Ci Laden Marpaung , Hal 15

${ }^{7}$ P.A.F Lamintang, Op.Cit. hal. 28 
c) Een ander atau orang lain

Seperti yang telah diuraikan, tindak pidana pembunuhan itu merupakan suatu tindak pidana materiil atau materieel delict, yakni suatu tindak pidana yang baru dapat dianggap sebagai telah selesai dilakukan oleh pelakunya dengan timbulnya akibat yang terlarang atau yang tidak dikehendakai oleh undang-undang.

\section{Tindak Pidana Pembunuhan Dengan Direncanakan Lebih Dulu}

Tindak pidana pembunuhan dengan direncanakan terlebih dahulu yang oleh pembentuk undang-undang telah disebut dengan kata moord itu diatur dalam Pasal 340 KUHP yang rumusannya sebagai berikut : “ barang siapa dengan sengaja dan dengan direncanakan terlebih dahulu menghilangkan( merampas) nyawa orang lain, diancam karena pembunuhan berencana, dengan pidana mati atau pidana penjara seumur hidup atau selama waktu tertentu , paling lama dua puluh tahun,"

Sedangkan rumusan ketentuan pidana pembunuhan dengan direncanakan terlebih dahulu di atas dapat di ketahui bahwa tindak pidana pembunuhan sebagaimana yang dimaksud dalam Pasal 340 KUHP mempunyai unsur-unsur sebagai berikut :

I. Unsur subjektif :

a) Dengan sengaja

b) Direncanakan terlebih dahulu.

2. Unsur objektif :

a) Menghilangkan

b) Nyawa

c) Orang lain.

Semua unsur tindak pidana pembunuhan di atas itu telah dibicarakan pada waktu membicarakan tindak pidana pembunuhan dalam bentuk pokok dan tindak pidana pembunuhan dengan keadaankeadaan yang memberatkan, kecuali unsur direncanakan terlebih dahulu (voorbedachte raad ) dan tentang apayang sebenernya dimaksud dengan kata voorbedachte raad atau direncanakan lebih dahulu itu Undang-Undang ternyata telah tidak memberikan penjelasannya, hingga wajar apabila di dalam doktrin timbul pendapatpendapat untuk menjelaskan arti yang menjelasakan dari kata voorbedachte raad tersebut.

Profesor SIMONS. ${ }^{8}$ berpendapat “ orang hanya dapat berbicara tentang adanya perencanaan lebih dahulu, jika untuk melakukan suatu

${ }^{8}$ P.A.F Lamintang Op. Cit hal. 53 
tindak pidana itu pelaku telah menyusun keputusannya dengan mempertimbangkan secaratenang, demikian pula telah mempertimbangkan tentang kemungkinan -kemungkinan dan tentang akibat-akibat dari tindakannya. Antara waktu seorang pelaku menyusun rencananya dengan waktu pelaksanaan dari rencana tersebut slalu harus terdapat suatu jangka waktu tertentu, dalam hal seorang pelaku dengan segera melaksanakan apa yang ia dimaksud untuk dilakukan kiranya sulit untuk berbicara tentang adaya suatu perencanaan terlebih dahulu.

\section{Tindak Pidana Pembunuhan Dengan Keadaan-Keadaan Yang Memberatkan}

Ketentuan pidana tentang tidak pidana pembunuhan dengan keadaan-keadaan yang memberatkan ataupun yang di dalam doktrin juga sering disebut sebagai gequalificeerde doodslag itu oleh pembentuk undang-undang telah diatur dalam pasal 339 KUHP yang rumusannya dalam bahasa belanda berbunyi sebagai berikut : Doodslag gevolgd, vergezeld of voorafgegaan van een strafbaar feit en gepleegd met het oogmerk om de uitvoering van dat feit voor te bereiden of gemakkelijk te maken, of om, bij betrapping op heter daad,aan zich zelven of aan andere deelnemers aan dat feit het zij straffeloosheid, hetzij het bezit van wederrechtelijk vergregene te verzekeren, wordt gestraft met levenslange gevangenisstraf of tijdelijke van ten hoogste twintig jaren ${ }^{9}$

Artinya : Pembunuhan yang diikuti, disertai atau didahului dengan suatu tindak pidana dengan maksud untuk menyiapkan atau memudah pelaksanaan dari tindak pidana tersebut atau jika kepergok pada waktu melakukan tindak pidana, untuk menjamin dirinya sendiri atau lain-lain peserta dalam tindak pidana, baik dalam usaha melepaskan diri dari pemidanaan maupun dalam mempertahankan penguasaan atas benda yang telah diperoleh dengan melawan hukum, dipidana dengan pidana penjara seumur hidup atau dengan pidana selama-lamanya dua puluh tahun.

Katasengaja dalam tindak pidana pembunuhan dengan keadaan keadaan yang memberatkan ini, sama halnya dengan dalam tindak pidana pembunuhan dalam bentuk pokok yang tercantum dalam pasal $338 \mathrm{KUHP}$, hanya saja ia harus diartikan secara luas yakni tidak semata-mata sebagai opzet als ogmerk saja melainkan juga sebagai opzet bij zekerheidsbewustjizn dan sebagai opzet bij mogelijkheidsbewustzijn.

Sedangkan dalam rumusan pasal 339 KHUP kata maksud / oogmerk sebagai unsur subjektif yang kedua itu harus diartikan sebagai

${ }^{9}$ P.A.F Lamintang Op. Cit. hal. 42 
maksud pribadi dari pelaku. Setelah diketahui, dalam pembicaraan penulis mengenai permasalahan yakni di dalam seseorang disebut sebagai mempunyai opzet terhadap timbulnya suatu akibat yang tidak dikehendaki oleh undang-undang. Terdapat dua paham yakni paham menurut teori kehendak (wilstheorie) dan paham menurut teori pekiraan ( voorstellingstheorie ).

\section{Perlunya Penyertaan Pembunuhan dipidana}

Penyertaan berasal dari kata deelneming berasal dari kata deelnemen yang terjemahannya " menyertai". ${ }^{\text {o }}$ Deelneming dipermasalahkan dalam hukum pidana, karena kenyataanya sering suatu delik dilakukan bersama oleh beberapa orang. Jika hanya satu orang yang melakukan suatu delik, pelakunya disebut alleen dader.

Prof Satochid Kartanegara mengartikan deelneming apabila dalam suatu delik tersangkut beberapa orang atau lebih dari satu orang. ${ }^{\text {II }}$ Pendapat ini kurang tepat, karena walaupun tersangkut beberapa orang, jika hanya satu orang yang dapat dipertanggungjawabkan, perbuatan tersebut tidak termasuk deelneming. Lebih tepat jika deelneming diartikan suatu delik yang dilakukan lebih dari satu orang yang dapat dipertanggungjawabkan.

Menurut dokrtin deelneming menurut sifatnya terdiri atas :

I.Deelneming yang berdiri sendiri, yakni pertanggung jawaban dari peserta dihargai sendiri-sendiri.

2. Deelneming yang tidak berdiri sendiri, yakni pertanggungjawaban dari peserta yang satu digantungkan pada perbuatan peserta yang lain. ${ }^{12}$

Deelneming diatur dalam Pasal 55 dan Pasal 56 KUHP. Untuk lebih jelasnya perlu dicermati Pasal-Pasal tersebut. Pasal 55 KUHP berbunyi:

r.Dipidana sebagai pembuat delik:

a) Mereka yang melakukan, yang menyuruh melakukan, dan yang turut serta melakukan perbuatan ( tindak pidana )

b) Mereka memberi atau menjanjikan sesuatu, dengan menyalahgunakan kekuasaan, atau martabat, dengan kekerasan, ancaman atau penyesatan, atau dengan memberi kesempatan, sarana atau keterangan, sengaja menganjurkan orang lain supaya melakukan perbuatan.

${ }^{10}$ P.A.F Lamintang $O p$. Cit Hal.77

${ }^{11}$ Satochid Kartanegara, Hukum Pidana Bagian I, Balai Lektur Mahasiswa, hal.497

${ }^{12}$ Ibid,hal.498 
2. Terhadap penganjur, hanya perbuatan yang sengaja dianjurkan sajalah yang diperhitungkan, beserta akibat-akibatnya.Pasal 56 KUHP berbunyi:"Sedangkan pembantu kejahatan dihukum :

a) Mereka yang dengan sengaja membantu waktu kejahatan dilakukan

b) Mereka yang dengan sengaja memberi kesempatan, ikhtiar atau keterangan untuk melakukan kejahatan itu"

Berdasarkan rumusan Pasal 55 KUHP dan 56 KUHP tersebut terdapat 5 peranan pelaku,yakni

I.Orang yang melakukan (dader or doer)

2. Orang yang menyuruh melakukan (doenplager)

3. Orang turut melakukan ( madedader)

4. Orang yang sengaja membujuk (uitlokker)

5. Orang yang membantu melakukan (medeplichtige).

Agar kalimat hal tersebut lebih jelas, perlu dicermati dengan seksama, 5 golongan diatas.

Sedangkan berkaiatan dengan penyertaan dalam pidana pembunuhan subjek hukum yang disebutkan dan dimaksud dalam rumusan tindak pidana adalah satu orang, bukan beberapa orang sebagai contoh pada Pasal 338 KUHP yang berbunyi:"barang siapa dengan sengaja menghilangkan nyawa orang lain, diancam karena pembunuhan dengan pidana penjara setinggi-tingginya lima belas tahun"

Berdasarkan uraian diatas jelas bahwa subjek hukumnya terletak pada kata "barang siapa" yang adalah orang, dan orang ini hanyalah satu, begitupun pada pembunuhan yang dilakukan secara bersama-sama, dalam rumusan Pasal 338 KUHP yang dimaksud orang itu hanya satu orang, apabila hanya berdasarkan semata-mata rumusan Pasal 388 KUHP saja, maka bila terjadi pembunuhan misalnnya contoh: si mahmud membantu memegangi anton supaya tidak melawan, sehingga dengan mudah codet membacok anton sehingga meninggal, maka mahmud tidak dapat dipidana kerena apayang dilakukannya dalam kasus pembunuhan anton tidak memenuhi rumusan Pasal $338 \mathrm{KUHP}$, dia hanya melakukan sebagian saja dari unsur dari perbuatan tersebut. Dari perbuatan mahmud memegangi tangan, tidaklah menimbulkan kematian anton, walaupun perbuatan masing-masing mahmud mempunyai andil atau peran terhadap kelancaran codet melakukan kejahatan itu dapat diselesaikan oleh codet sendiri yaitu menikam pada pembunuhan.

Dari peristiwa diatas, tampak jelas bahwa apabila didasarkan pada rumusan kejahatan Pasal 338 KUHP semata-mata, tentulah mahmud karena perbuatannya memegang tangan, pasti tidak dapat dipidana, karena 
tidak sesuai rumusan Pasal 338 KUHP, agar dapat mahmud juga dipidana harus ada ketentuan lain yang membebani pertanggungjawaban atas perbuatan seperti itu, dengan maksud demikian maka dibentuklah ketentuan umum penyertaan yang dimuat dalam Bab V buku I( Pasal 55 62 ) KUHP. Dengan berdasarkan ketentuan perihal penyertaan ini, maka mahmud dibebani tanggung jawab pidana dan karenanya dapatlah dipidana pula.

\section{Pembuktian Saksi Mahkota Dalam Kasus Pembunuhan}

Pembuktian mengandung maksud dan usaha untuk menyatakan kebenaran atas sesuatu peristiwa, sehingga dapat diterima akal terhadap kebenaran peristiwa tersebut. ${ }^{13}$ Sedangkan secara umum ketentuan ketentuan yang penggarisan dan pedoman tatacara yang dibenarkan undang - undang membuktikan kesalahan yang didakwakan kepada terdakwa, persidangan tidak boleh semena - mena membuktikan kesalahan seorang terdakwa. Sedangkan pembuktian menurut Martiman Projohamidjojo dapat diartikan sebagai suatu keseluruhan dari unsur unsur hukum pembuktian yang berkaitan dan berhubungan satu dengan yang lain serta saling pengaruh mempengaruhi dalam suatu keseluruhan atau kebulatan ${ }^{14}$

Pembuktian dalam hukum pidana biasa diatur dalam pasal 183 KUHAP yang berbunyi : hakim tidak boleh menjatuhkan pidana kepada seorang kecuali apabila sekurang - kurangnya dua alat bukti yang sah ia memperoleh keyakinan bahwa suatu tindak pidana benar - benar terjadi dan bahwa terdakwalah yang bersalah melakukannya, dari uraian tersebut dengan jelas bahwa KUHAP menganut sistem pembuktian negatife wettlijk yakni:

- Wettelik : adanya alat bukti yang sah yang telah ditetapkan Undang - Undang

- Negatife : adanya keyakinan ( nurani) dari hakim, yakni berdasarkan bukti- bukti tersebut hakim meyakini kesalahan terdakwa .

Adapun alat bukti yang sah telah ditetapkan oleh undang - undang adalah berdasarkan Pasal I84 KUHAP yaitu:

a) Keterangan saksi;

${ }^{13}$ Hari Sasangko, Hukum Pembuktian Dalam Perkara Pidana, Bandung Penerbit Mandar Maju, 2003, hal 11

${ }^{14}$ Setyo utomo, pembalikan beban pembuktian tindak pidana korupsi ( asas praduka tidak bersalah dalam negara hukum), Sofmedia, 2014,Hal 153. 
b) Keterangan ahli;

c) Surat ;

d) Petunjuk;

e) Keterangan terdakwa.

Bahwa dalam konteks di atas, kesaksian atau keterangan saksi merupakan alat bukti yang paling pertama dan dimungkinkan yang paling utama disebutkan dalam pasal I84 KUHAP, walaupun tidak semua perkara pidana menggunakan keterangan saksi, tetapi sebagian besar alat bukti untuk membuktiksn terdakwa bersalah ataukah tidak adalah keterangan saksi disamping alat bukti yang lain. Jika dihubungkan dengan ketentuan Pasal I butir 27 dan Pasal 185 ayat (I) KUHAP yang harus diterangkan adalah tentang apa yang seorang saksi lihat, saksi dengar, dan saksi ketahui tentang peristiwa hukum yang disampaika dalam proses pembuktian dalam persidangan yang merupakan satu alat bukti, begitu pentingnya saksi maka berdasarkan pasal 186 ayat 6 huruf (d) KUHAP untuk mengukur saksi tersebut hakim tidak hanya melakukan penilaian terhadap apayang diterangkan saksi tetapi menilai kesungguhan saksi di dalam memberikan keterangan ${ }^{15}$

Dalam praktek antara seorang terdakwa dengan terdakwa lain yang bersama - sama melakukan tindak pidana, bisa dijadikan sebagai saksi antara yang satu dengan yang lain, saksi yang diajukan seperti yang diterangkan disebut juga sebagai saksi mahkota ( kroongetuige), pada saat yang lain dijadikan terdakwa terhadap berkas pemeriksaaan tersangka dipisah, atau juga sering disebut dengan pemeriksaan berkas perkara (splitsing) hal ini dilakukan karena kurangnya saksi untuk menguatkan dakwaan penuntut umum, sehingga ditempuh cara mengajukan sesame tersangka sebagai saksi atau tersangka yang lain, diatur Pasal 142 KUHAP. kemungkinan yang timbul para terdakwa diperiksa seperti ini salaing memberatkan atau juga saling meringankan contohnya saja salah satu penyebab bebasnya kasus marsinah yang menggemparkan dengan praktik splitsing tersebut ${ }^{16}$

Menurut R. Soesilo, saksi mahkota yaitu saksi yang ditampilkan dari beberapa terdakwa atau salah seorang terdakwa guna membuktikan kesalahan terdakwa yang dituntut; saksi mahkota dapat dibebaskan dari tuntutan pidana atau kemudian akan dituntut pidana secara tersendiri

${ }^{15}$ Ib Id , Hal 169

${ }^{16}$ Hendrik Fasco Siregar, Keterangan Saksi Yang Tidak Dapat Dipercaya Dan Perlindungan Hukum Terdakwa, Yogjakarta : Samudera Biru 2019, Hal 104 
tergantung dari kebijaksanaan penuntut umum yang bersangkutan ${ }^{17}$ Sedangkan yang mendasari penggunaan saksi mahkota diatur dalam Pasal I42 Kitab Undang- Undang Acara Pidana (KUHAP), tujuan pemecahan berkas itu sendiri agar seorang terdakwa dengan terdakwa yang lain, masing-masing dapat dijadikan sebagai saksi secara timbal balik., sebagaimana pasal 168 huruf b KUHAP secara implisit mengatur tentang saksi mahkota. Selain itu pengaturan mengenai penerapan saksi mahkota juga bisa kita temukan dalam Putusan Mahkamah Agung No. 1986 $\mathrm{K} / \mathrm{Pid} / \mathrm{I} 989$ tanggal 2I Maret 1990, yang pada pokoknya menjelaskan "Penuntut Umum/Jaksa diperbolehkan mengajukan teman terdakwa sebagai saksi, yang disebut "saksi mahkota (kroongetuige)", asalkan perkara terdakwa dipisahkan dari perkara saksi tersebut (terdakwa dan saksi tidak termasuk dalam satu berkas perkara.

Doktrin hukum yang menyatakan bahwa prinsip saksi mahkota itu tidak boleh digunakan adalah karena melanggar hak asasi manusia yang mana terdakwa tidak bisa menggunakan hak mungkir karena terkena sumpahnya ketika menjadi saksi di dalam persidangan, Mahkamah Agung bermaksud meluruskan hal ini yang tertuang di dalam Putusan Mahkamah Agung No ${ }_{1174} \mathrm{~K} / \mathrm{Pid} / 1994$ tanggal 25 April 1995 dengan terdakwa Ny.Mutiari SH dan Putusan Mahkamah Agung No 1952 K/Pid/1994 tanggal 25 April 1995 dengan terdakwa Bambang Wuryantoyo, Widayat, dan Ahmad Sutiyono Prayogi, dengan Ketua Majelis Hakim Agung Adi Andojo Soetjipto, SH.,telah memberikan pertimbangan sebagai berikut: "oleh karena judex Facti telah salah menerapkan hukum pembuktian dimana saksi adalah para terdakwa dalam perkara dengan dakwaan yang sama yang dipecah - pecah adalah bertentangan dengan hukum acara pidana yang menjuung hak asasi manusia, lagi pula para terdakwa telah mencabut keterangannya di depan penyidik dan pencabutan tersebut beralasan karena adanya tekanan Fisik maupun Psikis dapat dibuktikan secara nyata disamping itu saksi - saksi yang lain yang diajukan ada persesuaian antara satu sama yang lain berdasarkan pertimbangan tersebut maka terdakwa dibebaskan. ${ }^{18}$

Apabila kita kaji doktri hukum di atas maka perlunya kita mengerti bahwa seorang terdakwa juga mempunyai hak - hak yang harus dilindungi terkait proses pembuktian yang tercantum dalam asas praduga tidak bersalah yang mana terdakwa tidak dibebani kewajiban pembuktian sebagaimana Pasal 66 KUHAP, ketentuan ini merupakan penjelamaan

${ }^{17}$ R.Soesilo, Teknik Berita Acara (Proses Verbal), Ilmu Bukti, dan Laporan, Politeia, Bogor, 1980, hlm 7

18 Op Cit, Hendrik Fasco Siregar, Hal 105 
presumption of innocence, dalam hukum acara pidana yang dikenal dengan asas " siapa yang menyangka / atau mendakwa diwajibkan kebenaran dari dakwaan”'

Karena dalam proses pemeriksaan pidana yang membuat dan yang menyampaikan adalah jaksa penuntut umum, maka yang dibebani kewajiban untuk membuktikan kesalahan terdakwa adalah jaksa penuntut umum ( burden of proof is always on the prosecutor), akan tetapi menurut ketentuan yang diatur dalam KUHAP dan dalam praktek proses perdailan perkara pidana pada umunya, majelis hakim dalam sidang pengadilan secara efektif juga membuktikan kesalahan terdakwa berdasarkan surat dakwaan yang dibuat oleh penuntut umum.

\section{Keterangan Terdakwa Dalam Persidangan Kolerasinya Dengan Saksi Mahkota}

Kesaksian yang diberikan oleh seorang terdakwa terhadap terdakwa lain ( saksi mahkota) maka kita perlu menerangkan terlebih dahulu kekuatan keterangan terdakwa dalam pengadilan agar lebih jelas kedudukan antara keterangan terdakwa atau sebagai saksi.

Alat bukti keterangan terdakwa merupaka urutan terakhir dalam Pasal I84 ayat (I) KUHAP, penempatannya pada urutan terakhir merupakan salah satu alasan untuk menempatkan proses pemeriksaan keterangan - saksi , keterangan terdakwa adalah suatu pernyataan yang di tuangkan di depan pengadilan tentang perbuatan yang ia lakukan, atau ia ketahui sendiri atau ia alami sendiri sebagaimana Pasal i89 ayat (I) KUHAP.

Keterangan Terdakwa tidak perlu sama dengan pengakuan terdakwa, sebagai alat bukti harus mempunyai syarat - syarat :

I) Mengaku ia melakukan delik yang di dakawakan dan;

2) Megaku ia bersalah ${ }^{20}$.

Sedangkan kekuatan keterangan terdakwa yang memberikan kesaksian bagi terdakwa lainnya menjadi keterangan saksi walaupun status hukumnya sebagai terdakwa, hal ini dipertegas dalam penggunaan saksi mahkota oleh kejaksaan Agung Republik Indonesia, bahwa penggunaan saksi mahkota apabila minim alat bukti bila terjadi (delneming) dengan pertimbangan bahwa dalam status sebagai terdakwa keteranganya hanya

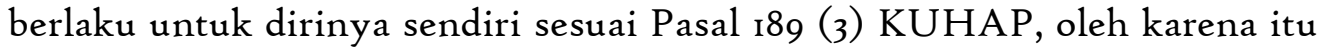
dengan berpedoman pada pasal 142 KUHAP, maka berkas perkara harus

19 Op Cit Hendrik Fasco Siregar, Hal 31

${ }^{20} \mathrm{Al}$ fitra, hukum pembuktian dalam beracara pidana, perdata, dan korupsi di Indonesia, depok, Raih asa sukses, 2011, Hal 111 
diadakan pemisahan ( splitsing) agar para terdakwa disidangkan terpisah sehingga antara para terdakwa menjadi saksi satu dengan yang lain.

Terdakwa memberikan sebuah keterangan atau kesaksian untuk terdakwa yang lain, saksi mahkota menjadi kunci dalam pemecahan kasus yang melibatkan beberapa pelaku. Splitsing itu sendiri mempunyai makna terdakwa atau tersangka dapat menjadi saksi mahkota untuk memberikan kesaksian dalam menanggulangi kejahatan ${ }^{2 \mathrm{I}}$

Penggunaan saksi mahkota peradilan pidana sudah terbiasa dilakasanakan namun kondisi demikian tidak berarti bahwa jaksa penuntut umum dapat begitu saja menghadirkan saksi mahkota di muka persidangan. Penggunaan saksi mahkota dengan mekanisme (splitsing) dalam proses pembuktian di sidang pengadilan bertentangan dengan asas non self incrimination yang secara tersirat tercermin secara parsial melalui beberapa pasal yaitu Pasal 66 KUHAP bahwa tidak ada beban kewajiban pembuktian bagi terdakwa (beban pembuktian menjadi kewajiban penuntut umum), Pasal 175 KUHAP yang meyiratkan adanya hak ingkar bagi terdakwa, Pasal 189 ayat (3) KUHAP bahwa keterangan terdakwa hanya dapat dipergunakan bagi dirinya sendiri, dan tidak adanya pengakuan terdakwa sebagai alat bukti yang sah sebagaimana diatur dalam Pasal I84 KUHAP, serta Pasal I68 KUHAP mengenai pengecualian yang bersifat relatif untuk menjadi saksi.

Selain aturan di atas penggunaan saksi mahkota juga haruslah sesuai dengan surat edaran Kejakasaan Agung Republik Indonesia No.B69/E/02/1997 perihal hukum pembuktian dalam perkara pidana yang menyatakan : saksi mahkota di gunakan dalam hal terjadi penyertaan dimana terdakwa yang lainya dijadikan saksi terhadap terdakwa lainnya karena alat bukti yang lain tidak ada atau sangat minim, dengan pertimbangan sebagai status terdakwa keterangnya hanya berlaku untuk dirinya sendiri dan harus pemisahan berkas perkara.

\section{Keterangan Saksi Mahkota Farilham Jayadi Als Pepen Sebagai Pertimbangan Hakim Memutuskan Terdakwa Bersalah Dalam Putusan 334/Pid.B/2014/Pn/Dpk}

Di dalam putusan ini saksi mahkota yang bernama Farilham Jayadi Als Pepen mengakui secara tegas dan bersalah tanpa paksaan telah melakukan tindak pidana pembunuhan dengan terdakwa Sarifudin Als Boren Bin Ramin dengan cara saksi mahkota membekap mulut dan

\footnotetext{
${ }^{21}$ Sutarto, hukum acara pidana jilid I, semarang, badan penerbit undip, 1191,Hal
} 
mencekik leher korban sedangkan terdakwa memegangi tangan korban. Dimana peristiwa itu terjadi pukul o4:0o WIB atau setidak-tidaknya pada suatu waktu pada bulan Maret Tahun 2014, bertempat di dekat pos Pemuda Pancasila dekat bensin biru Kel. Kalimulya. Kec. Cilodong Kota Depok atau setidak-tidaknya di suatu tempat yang masih masuk dalam daerah Hukum Pengadilan Negeri Depok

Adapun alasan - alasan saksi mahkota dengan terdakwa melakukan pembunuhan itu disebabkan karena kurangnya pendidikan yang dimilki pelaku kejahatan dimana pelaku tidak berpikir terlebih dahulu dan akibat dari tindakannya kemudian, yang didasari dari keyakinan pelaku atas perkataan saksiFarilham Jayadi Als Pepen tentang batu cincin yang membuat orang memakainya bisa kebal dan menghilang dengan syarat diikat dengan "tali pocong perawan" atau "diolesi air mani perwan" itulah yang membuat pelaku melakukan tindak pidana pembunuhan

Sedangkan hakim menilai antara terdakwa dan saksi mahkota memberikan keterangan yang tidak bertentangan antara yang satu dengan yang lain sehingga hakim di dalam pertimbangannya menyatakan terdakwa telah terbukti bersama - sama dengan saksi melakukan tindak pidana pembunuhan dengan korban Anita Ambarwati, sebagaimana Pasal 338 Jo Pasal 55 Ayat I Ke-IKUHP.yang berbunyi tindak pidana yang melakukan,yang menyuruh melakukan, dan turut serta dalam melakukan merampas nyawa orang lain.

Bahwa berdasarkan katerangan saksi mahkota Farilham jayadi dan diakui oleh terdakwa Saripudin Als Boren, mereka mengakui dengan secara bersama - sama melakukan pembunuhan dengan cara tidak sengaja menghilangkan nyawa korban dengan cara tercekik.

\section{KESIMPULAN}

Berdasarkan uraian yang telah penulis jelaskan di atas penerapan saksi mahkota dalam kasus pembunuhan yang dalam putusan No: 334/Pid.B/2014/Pn/Dpk, sudah sesuai dengan hukum acaara pidana dan tidak melanggar hak asasi manusia karena dilaksanakan tanpa adanya paksaaan dan tekanan fisik terhadap para terdakwa selain itu juga keterangan saksi mahkota bersesuaian dengan satu dengan yang lainya. Berbeda apabila dilaksanakan dalam tekanan dan paksaan yang terjadi penolakan pemberian keterangan oleh saksi mahkota maka melanggar asas non self incrimination yang tertera secara parsial melalui Pasal 66 KUHAP bahwa tidak ada beban kewajiban pembuktian bagi terdakwa (beban pembuktian menjadi kewajiban penuntut umum), Pasal 175 KUHAP yang menyiratkan adanya hak ingkar bagi terdakwa, Pasal 189 
ayat (3) KUHAP bahwa keterangan terdakwa hanya dapat dipergunakan bagi dirinya sendiri, dan tidak adanya pengakuan terdakwa sebagai alat bukti yang sah sebagaimana diatur dalam Pasal I84 ayat (I) KUHAP, serta Pasal 168 KUHAP tentang pengecualian yang bersifat relatif untuk menjadi saksi. Sedangkan peran saksi mahkota dalam menyingkap tindak pidana pembunuhan sangatlah penting apabila di dalam proses pembuktian penuntut umum kekurangan alat bukti atau minim alat bukti untuk membuka tabir siapa pelaku dalam tindak pidana pembunuhan sebagaimana, tetapi harus di barengi atau tambahan alat bukti yang lain agar tidak terjadi lagi putusan pembunuhan marsinah saksi mahkota yang bertentangan dengan hukum.

\section{DAFTAR PUSTAKA}

Al fitra, hukum pembuktian dalam beracara pidana, perdata, dan korupsi di Indonesia, depok, Raih asa sukses, 20II,

Adami Chazawi, Kemahiran \& Keterampilan Praktik Hukum Pidana,Malang: Bayu Penerbit,2006

Alfitra,Hukum Pembuktian Dalam Beracara Pidana, Perdata Dan Korupsi Di Indonesia Edisi Revisi,Depok:RAS,2012

Andi Hamzah,KUHP\&KUHAP Edisi Revisi,Jakarta:Rineka Cipta,20o8

E.Y.Kanter,Asas-Asas Hukum Pidana Di Indonesia Dan Penerapannya, Jakarta:Storia Grafika, 2012.

Iqbal, Muhamad. "IMPLEMENTASI EFEKTIFITAS ASAS OPORTUNITAS DI INDONESIA DENGAN LANDASAN KEPENTINGAN UMUM."Jurnal Surya Kencana Satu: Dinamika Masalah Hukum dan Keadilan 9.I (2018).

Iqbal, Muhamad. "Perkembangan Kejahatan Dalam Upaya Penegakan Hukum Pidana: Penanggulangan Kejahatan Profesional Perdagangan Organ Tubuh Manusia." PROCEEDINGS. Vol. 2. No. I. 2017.

Jimly Asshiddihie, Menuju Negara Hukum Yang Demokratis, Jakarta:PT Bhuana Ilmu Populer,2009

Laden Marpaung, Asas-Teori-Praktik Hukum Pidana,Jakarta:Sinar Grafika,2005

Lamintang, delik- delik khusus kejahatan terhadap nyawa, tubuh \& kesehatan" Jakarta: sinar Grafika,2oı,

luhut M.P. Pangaribuan ,Hukum Acara Pidana Edisi Revisi , Jakarta:ISBN,2005

Moeljatno, Asas-Asas Hukum Pidana, Jakarta:Sinar Grafika,20oI

Satochid Kartanegara, Hukum Pidana Bagian I , Balai Lektur Mahasiswa,Jakarta, 1962-1963

Setyo utomo, pembalikan beban pembuktian tindak pidana korupsi ( asas praduka tidak bersalah dalam negara hukum), Sofmedia, 2014 
Soedjono,Asas Penerapan Hukum Pidana,Jakarta: Fasco,I99I

Sutarto, hukum acara pidana jilid I, semarang, badan penerbit undip, II9I

Van Bemmelen, Hukum Pidana I, Bandung: Bina Cipta,I987

WirjonoProdjodikoro, Asas-assaHukumPidanaIndoneia, Jakarta: PT. Eresco, 1967

Hendrik Fasco Siregar, Keterangan Saksi Yang Tidak Dapat Dipercaya Dan Perlindungan Hukum Terdakwa, Yogjakarta : Samudera Biru 2019,

R.Soesilo, Teknik Berita Acara (Proses Verbal), Ilmu Bukti, dan Laporan, Politeia, Bogor, 1980,

Romli Amasasmita, Sistem Peradilan Pidana Kontemporer, Kencana Prenada Media Group, Jakarta, 20II

UNDANG - UNDANG

Undang-Undang Republik Indonesia Nomor 8 Tahun 198I tentang Hukum Acara Pidana, Lembaran Negara Republik Indonesia Tahun 198I

Undang-Undang Republik Indonesia Nomor 13 Tahun 2006 tentang Perlindungan Saksi dan Korban, Lembaran Negara Republik Indonesia Tahun 2006, Nomor 64, Tambahan Lembaran Negara Nomor 4635 .

Undang-Undang Republik Indonesia, Nortahun 1946, Tentang Kitab Undang-Undang Hukum Pidana

Undang-Undang Republik Indonesia, No 8 Tahun 198I, Tentang Kitab Undang-Undang Hukum Acara Pidana

Undang-Undang No2 Tahun 2002 Tentang Kepolisian

Undang -Undang 16 Tahun 2004 Tentang Kejaksaan

Undang- Undang No 48 Tahun 2009 TentangKehakiman 

